\title{
Effect of Surfactants on Cyclization of Bacillus macerans Cyclodextrin Glucanotransferase ${ }^{\dagger}$
}

\author{
Shoichi Kobayashi, Keiji KaInuma and Dexter French* \\ National Food Research Institute \\ (2-1-2, Kannondai, Yatabe, Tsukuba, Ibaraki 305, Japan)
}

(Received September 24, 1982)

\begin{abstract}
The action of cyclization of Bacillus macerans cyclodextrin glucanotransferase (BME) was studied by use of various kinds of surfactants. And it was elucidated by use of reducing end labelled maltosaccharides that cyclization proceeds from the non-reducing end of $\alpha-1,4$ glucan. Surfactants which have straight carbon chains as hydrophobic moiety were extremely effective in promoting the enzyme action forming $\alpha$-cyclodextrin $(\alpha-C D)$. On the other hand, surfactants which have more bulky hydrophobic moiety than straight carbon chains were extremely effective for $\beta$-CD formation ( $\beta$-CD forming surfactants).

By use of the dextrin, which was prepared from defatted waxy corn starch by the treatment with bacterial liquefying $\alpha$-amylase and $\beta$-amylase and from which only traces of CDs were formed by the action of BME without sodium lauryl sulfate (SDS), the enzyme action was changed so as to form mainly $\alpha-C D$ with $\alpha-C D$ forming surfactants and mainly $\beta$-CD with $\beta$-CD forming surfactants. And the rate of $\alpha-\mathrm{CD}$ formation from soluble starch in addition of SDS was 1.6 times as reference (without SDS).

Hydrolyzing activity was effectively depressed by the addition of SDS.

From these results the authors infer that cyclization proceeds on $6_{5}$-helices, $7_{6}$-helices to form $\alpha$ and $\beta$-CD from the non-reducing end of $\alpha-1,4$ glucans and so that the action pattern of BME depends not only on the specificity of the enzyme itself, but also on the conformation of the substrate as modified by helicogenic complexing agents.
\end{abstract}

Cyclization is the main reaction of the cyclodextrin glucanotransferase (BME) by which cyclodextrins are formed from $\alpha-1,4$ glucan such as amylose. BME catalyzes three other reactions; these are coupling, disproportionation and hydrolysis, and these occur at the same time. ${ }^{1,2}$ Because of this complexity, it has been very difficult to study each reaction separately. Nevertheless, some effort has been made to elucidate the action pattern of BME. ${ }^{3-6)}$

The authors have been working on the prepa-

\section{† This work was supported in part by grant of the NIH (GM-08822).}

S. Kobayashi and K. Kainuma wish to dedicate this paper to the warm memory of Professor Dexter French.

* Deceased on 26th November, 1981.

Department of Biochemistry and Biophysics, Iowa State University, Ames, Iowa 50011, U.S.A. ration of cyclodextrins (CDs) and they found that surfactants such as sodium lauryl sulfate (SDS) and isooctyl phenyl polyoxyethylene (Triton) were very effective in promoting the enzyme action forming $\alpha, \beta-\mathrm{CD}$ and branched CDs. ${ }^{7,8)}$

In this report, the authors try to elucidate the action of cyclization by use of various kinds of surfactants.

\section{EXPERIMENTAL}

Materials. Radioactive glucose: $\mathrm{D}-\left[\mathrm{U}-{ }^{14} \mathrm{C}\right] \mathrm{glu}-$ cose, $5.0 \mathrm{mCi} / \mathrm{mmol}$, Daiichi Kagaku Chemicals. Soluble starch for analytical use was purchased from Merck. $\alpha$-Cyclodextrin was prepared by the previously reported method. ${ }^{9)}$ BME was prepared, purified and crystallized by the previously reported method..2 $\alpha$-Amylase (liquefying), lyophilized $900 \mathrm{U} / \mathrm{mg}$ (BLA) was purchased from 
Seikagaku Kogyo Co., Ltd. Tokyo, Japan. $\beta$ Amylase from Ipomea batatas (suspension $10 \mathrm{mg} / 2$ $\mathrm{ml}$ ) was purchased from Boehringer Mannheim. Sodium lauryl sulfate (SDS, approx. 95\%) was purchased from Sigma.

Surfactants. The 13 kinds of surfactants were kindly donated by Kao Sekken Co. Ltd., Tokyo, Japan.

Preparation of reducing end labelled maltosaccharides. ${ }^{10)} \quad$ Radioactive glucose $(10 \mu \mathrm{Ci}), 10 \mathrm{mg}$ of $\alpha$-cyclodextrin and 20 THU of BME were mixed to make $1 \mathrm{ml}$ of reaction mixture, and reacted at $50^{\circ} \mathrm{C}$, pH 6.20 for $5 \mathrm{hr}$. The reaction mixture was inactivated in a boiling bath for $15 \mathrm{~min}$.

Preparation of branched dextrin. One $\mathrm{g}$ of defatted waxy corn starch was suspended in $100 \mathrm{ml}$ of water, pregelatinized and autoclaved at $120^{\circ} \mathrm{C}$ for $30 \mathrm{~min}$. Ten $\mathrm{ml}$ of $0.1 \mathrm{M}$ acetate buffer $(\mathrm{pH}$ 5.50), $2 \mathrm{ml}$ of $50 \mathrm{mM} \mathrm{CaCl}$ and $200 \mu \mathrm{l}$ of BLA solution $(1 \mathrm{mg}$ enzyme protein in $10 \mathrm{ml}$ of $10 \mathrm{~mm}$ acetate buffer, pH 5.5 containing $0.1 \mathrm{~mm} \mathrm{CaCl}_{2}$ ) were added to the starch solution and reacted at $40^{\circ} \mathrm{C}$ for $10 \mathrm{~min}$, inactivated in a boiling bath for $10 \mathrm{~min}$ (the digest showed brown color with iodinepotassium iodate solution).

Whole the digest was put into a Visking tube, to which $20 \mu 1$ of $\beta$-amylase suspension was added. The reaction mixture was simultaneously dialyzed at $40^{\circ} \mathrm{C}$ in 5 liters of $1 \mathrm{~mm}$ acetate buffer ( $\mathrm{pH} \mathrm{5.5)}$ for $45 \mathrm{hr}$. Furthermore, $200 \mu \mathrm{l}$ of $\beta$-amylase suspension was added to the dialyzate and reacted for $24 \mathrm{hr}$ in 2 liters of fresh buffer.

The reaction mixture was repeatedly dialyzed in 5 liters of hot water $\left(90^{\circ} \mathrm{C}\right)$ for $4 \mathrm{hr}$, then concentrated to $12 \mathrm{ml}$. The yield was $24 \mathrm{mg}$ $(2.4 \%)$, and the dextrin showed brown color with iodine-potassium iodate solution.

Two dimensional radioautogram. ${ }^{11)}$ Each $100 \mu 1$ of radioactive maltosaccharide solution was spotted on a paper for chromatography (size $30 \times 30$ $\mathrm{cm}, \mathrm{S}$ and $\mathrm{R}_{1}$ in Fig. 1a) and the paper was irrigated 3 times in the first direction at $65^{\circ} \mathrm{C}$ by $65 \%$ $n$-propyl alcohol. After cutting off the running area of $R_{1}$, the paper was sprayed with 6 THU of BME in $5 \mathrm{ml}$ of $1 \mathrm{mM}$ acetate buffer (pH 6.20) on the running area of $S$ uniformly, then reacted at $55^{\circ} \mathrm{C}$ for $1 \mathrm{hr}$ in a moist chamber, and inactivated in an oven at $90-100^{\circ} \mathrm{C}$ for $30 \mathrm{~min}$. The enzyme treated paper was irrigated twice in the second direction after attaching the $R_{1}$, exposed for 2 weeks on a sheet of X-ray film (Fuji X-ray film $\mathrm{K}_{\mathrm{x}}$, $25.4 \times 30.5 \mathrm{~cm})$ to make a radioautogram.

Determination of $\alpha$ and $\beta-C D$ (Fig. $6 a, 6 b$ ). Two hundred $\mu \mathrm{l}$ of reaction mixtures (total sugar, $4 \mathrm{mg}$ ) was streaked by $5 \mathrm{~cm}$ width on a paper $(30 \times$ $30 \mathrm{~cm}$ ). The paper was irrigated twice at $70^{\circ} \mathrm{C}$ by 1-propanol/1-butanol/water (5/3/4 parts by volume), then cut off the bands which were revealed by iodine-acetone solution. ${ }^{12}$ ) The pieces (about $1 \mathrm{~cm}$ square) was placed in a test tube, which contained $10 \mathrm{ml}$ of water. The test tube was put in a boiling bath for $10 \mathrm{~min}$, then $1 \mathrm{ml}$ of the supernatant was sampled for the determination of the total carbohydrate by phenol-sulfuric acid method. ${ }^{13)}$

Determination of hydrolyzing activity (Fig. 7). Defatted waxy maize starch was dissolved into water by autoclaving at $120^{\circ} \mathrm{C}$ for $30 \mathrm{~min}$. The final concentration of the reaction mixture was following; substrate $2 \%$, SDS $0.1 \%$, the amount of the enzyme $0.05 \mathrm{THU} / \mathrm{mg}$ substrate, acetate buffer $1 \mathrm{~mm}$ (pH 6.20).

Substrate and SDS were mixed and preincubated at $40^{\circ} \mathrm{C}$ for $5 \mathrm{~min}$, and enzyme solution was added, then reacted at $40^{\circ} \mathrm{C}$, pH 6.20 with stirring. One $\mathrm{ml}$ of the reaction mixture was periodically taken, and the reducing value was determined by the Somogyi-Nelson method. ${ }^{14)}$

\section{RESULTS AND DISCUSSION}

\section{Action pattern of cyclization}

As in Fig. 1a, reducing end labelled radioactive glucose, maltose, maltotriose, maltotetraose, .. were formed from reducing end labelled radioactive $G_{7}, G_{8}, G_{9}, G_{10}, \cdots$, but radioactive $C D s$ were not detected (the locations of $\alpha, \beta, \gamma-\mathrm{CD}$ are between $G_{4}$ and $G_{5}, G_{5}$ and $G_{6}, G_{6}$ and $G_{7}$ on this radioautogram). By staining with iodine acetone solution, $\alpha-C D$ was detected on the lines of $G_{7}$, $\mathrm{G}_{8}, \mathrm{G}_{9}, \mathrm{G}_{10}, \cdots$ (second direction). Namely, cyclization is exo-wise attack at the nonreducing end of the glucans (Fig. 1b). It is noted that the reaction preferably proceeds on $\mathrm{G}_{8}$ and $\mathrm{G}_{9}$, and that slower on $G_{11}$ and longer glucans than these. By use of non radioactive maltosaccharides, the same results were obtained.

SDS was considerably effective to proceed cyclization; the rate of $\alpha$-CD formation from soluble starch with SDS (containing SDS by $10 \%$ of sub- 


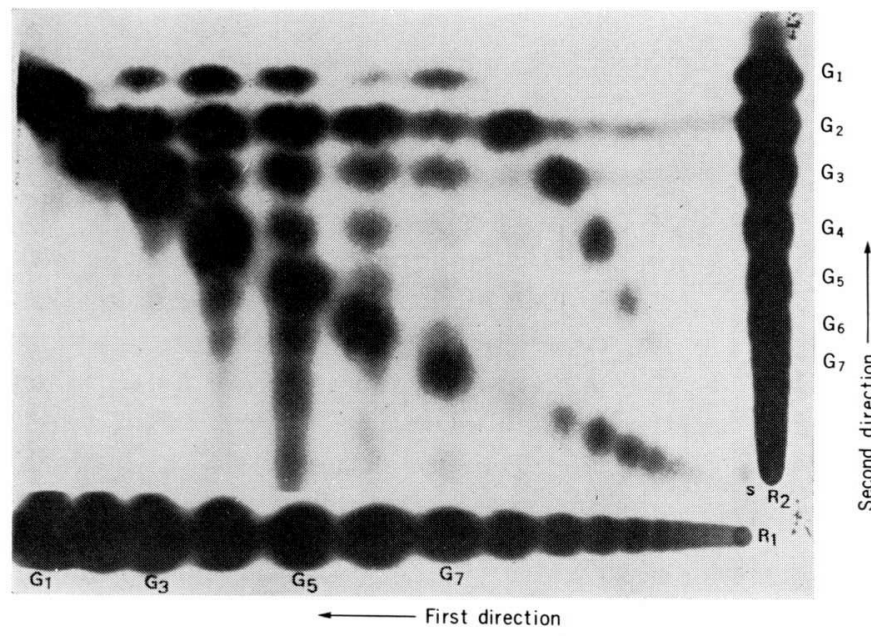

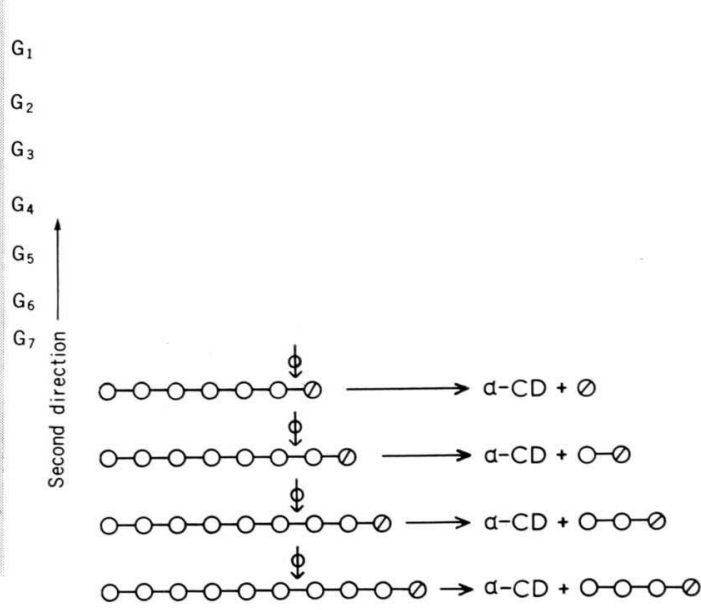

$\mathrm{b}$

Fig. 1. a: Two dimensional radioautogram showing the action pattern of BME (cyclization), b: action of BME (cyclization).

$\mathrm{S}, \mathrm{R}_{1}, \mathrm{R}_{2}$, see Experimental, Two dimensional radioautogram in the text; $\mathrm{G}_{1}-\mathrm{G}_{7}$, glucose-maltoheptaose.

$\bigcirc-$, Non-reducing end; $-\oslash$, reducing end; $\Phi$, cyclizing point.

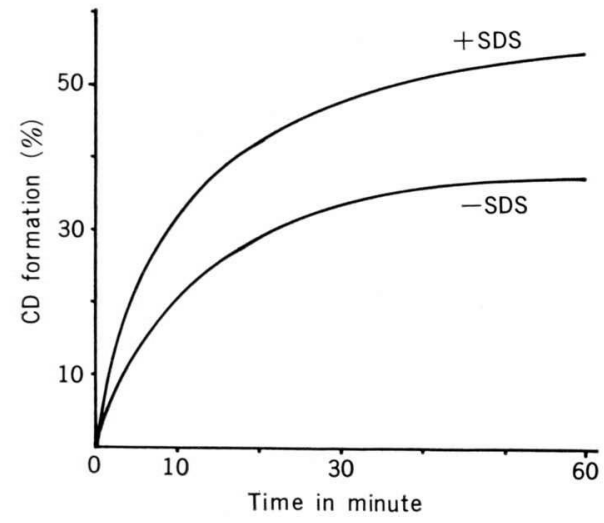

Fig. 2. Rate of cyclodextrin formation from soluble starch in the presence or absence of SDS.

Reaction condition: substrate concentration, final $0.5 \%$ (soluble starch, Merck, zur Analyse); enzyme concentration, $0.06 \mathrm{THU} / \mathrm{mg}$ substrate; final buffer concentration, $0.025 \mathrm{M}$ acetate buffer (pH 6.0).

-SDS, Reference (without SDS); +SDS, addition of SDS.

The reaction mixture was periodically taken off, and the amount of CD was determined by glucoamylase method. ${ }^{15)}$ At the initial stage of the reaction, $\alpha$-CD was mainly formed. strate) was 1.6 to 1 without SDS (Fig. 2), also various kinds of branched CDs were formed. These results suggest that cyclization proceeds on helices and helices attached with branches to form CDs and branched CDs, because SDS is effective reagent for helices formation. ${ }^{16-18)}$

\section{The effect of surfactants on cyclization}

As in Fig. 3, surfactants, Nos. 1, 4, 5, 6, 8, 10 and 11 were effective for $a$-CD forming, and their skeletal structures of hydrophobic moiety were straight 12 and 18 carbon chains (Fig. 4a). According to space filling molecular model, $6_{5}$-helices fit straight carbon chain and 6 glucose units make 1 pitch. Therefore, these surfactants could be effective to form $\alpha$-CD.

On the other hand, effective surfactants to form $\beta$-CD were Nos. 2, 3, 7, 9 and 12 (as in Figs. 3 and 4b). Their hydrophobic moieties are more bulky than straight carbon chain.

\section{Specific formation of $\alpha$ and $\beta-C D$}

It is thought that specific formation of $\alpha$ and $\beta$-CD is possible by use of $\alpha$ and $\beta-C D$ forming surfactants respectively. If the substrate that is resistant to the action of $\mathrm{BME}$ and does not form any CDs in the absence of surfactants is obtainable, the substrate will be used to elucidate the 


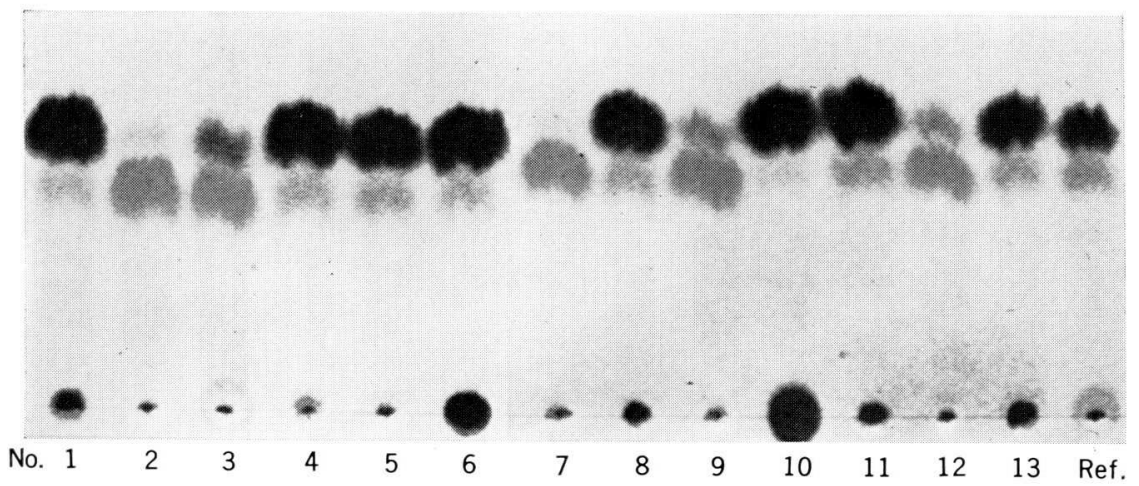

Fig. 3. Formation of cyclodextrins in the presence of various surfactants.

Nos. 1-13, see in Fig. 4a, 4b; Ref, reference (without surfactant).

$4 \%$ surfactants solutions, $2 \%$ soluble starch solution and BME solutions ( 24 THU in $1 \mathrm{ml}$ of $0.1 \mathrm{~m}$ acetate buffer containing $1 \mathrm{mM} \mathrm{CaCl} 2, \mathrm{pH} 6.0$ ) were prepared. $\quad 100 \mu \mathrm{l}$ of substrate solution and $50 \mu \mathrm{l}$ of surfactant solution were mixed and kept for $10 \mathrm{~min}$ at $40^{\circ} \mathrm{C}$, and added $50 \mu \mathrm{l}$ of enzyme solution, reacted at $40^{\circ} \mathrm{C}$ for $24 \mathrm{hr}$. Each $20 \mu \mathrm{l}$ of the reaction mixture was spotted on a paper $(20 \times 20 \mathrm{~cm}$, Toyo Roshi No. 50, Tokyo, Japan) and the paper was irrigated at $70^{\circ} \mathrm{C}$, twice by 1-butanol:1-propanol:water $(3 / 5 / 4)$, revealed by dipping in iodine-acetone solution.

$\alpha$-CD shows blue color, $\beta$-CD is yellow and $\gamma$-CD is yellowish orange.

a

$$
\begin{gathered}
\text { No. } \\
1 \\
4 \\
\\
5 \\
6 \\
8 \\
10 \\
11 \\
13
\end{gathered}
$$
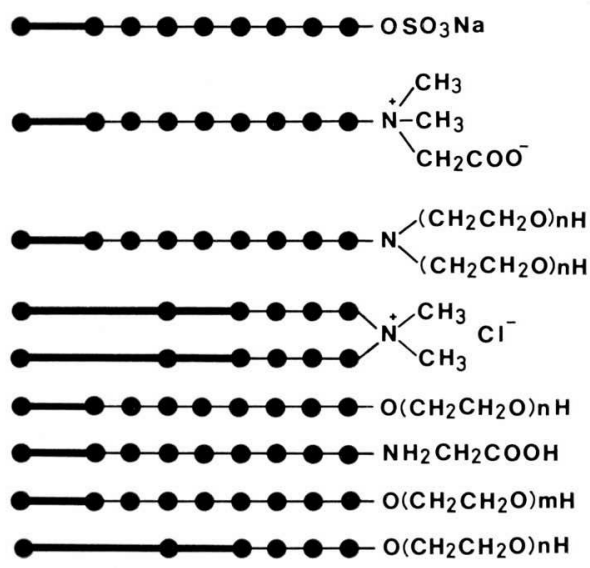

b

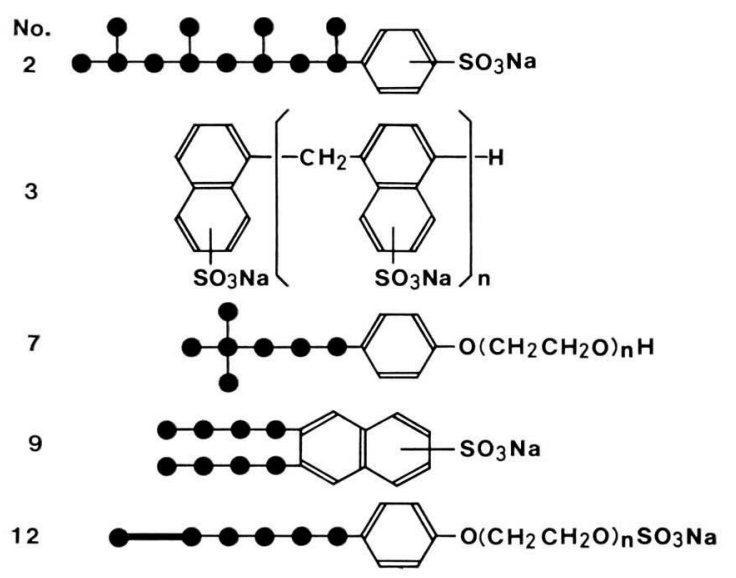

No.
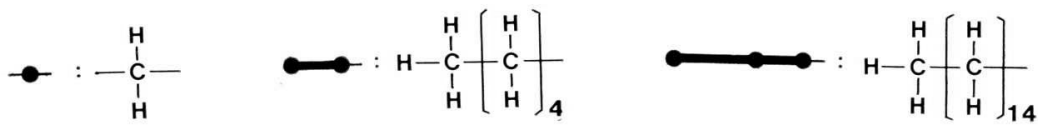

Fig. 4. a: The structure of surfactants forming $\alpha$-cyclodextrin, b: the structure of surfactants forming $\beta$-cyclodextrin.

mechanism of BME, and from this standpoint, $\alpha$ amylase and $\beta$-amylase treated waxy corn starch was prepared (preparation of branched dextrin in Experimental).
As in Fig. 5, without surfactant, trace of $\alpha$-CD was formed from the dextrin (Ref.). By the addition of the surfactant No. 4, a considerable amount of $\alpha$-CD was formed. $\beta$-CD was formed by No. 


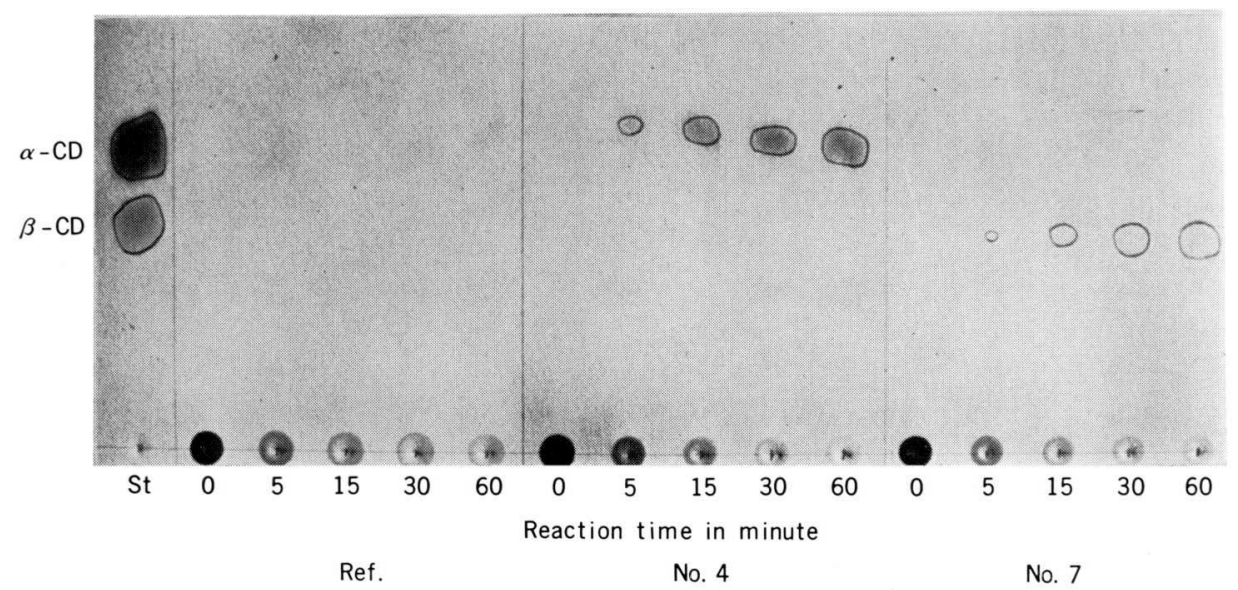

Fig. 5. Time course of cyclodextrins formation from a dextrin in the presence of $\alpha$ and $\beta$-cyclodextrin forming surfactants.

St, Standards of $\alpha$ and $\beta$-CD; Ref., reference (without surfactant); No. 4 , with No. 4 surfactant; No. 7 , with No. 7 surfactant.

Two hundred $\mu 1$ of $2 \%$ substrate solution (referred to preparation of branched dextrin in Experimental) and $100 \mu \mathrm{l}$ of $4 \%$ surfactant solution were mixed and kept at $40^{\circ} \mathrm{C}$ for $10 \mathrm{~min}$, added $100 \mu \mathrm{l}$ of BME solution (same as in Fig. 3) and reacted at $40^{\circ} \mathrm{C}$. Twenty $\mu$ l of the reaction mixture was periodically taken and spotted on a paper $(30 \times 35 \mathrm{~cm}$ wide), and a paper chromatogram was made as same as in Fig. 3.
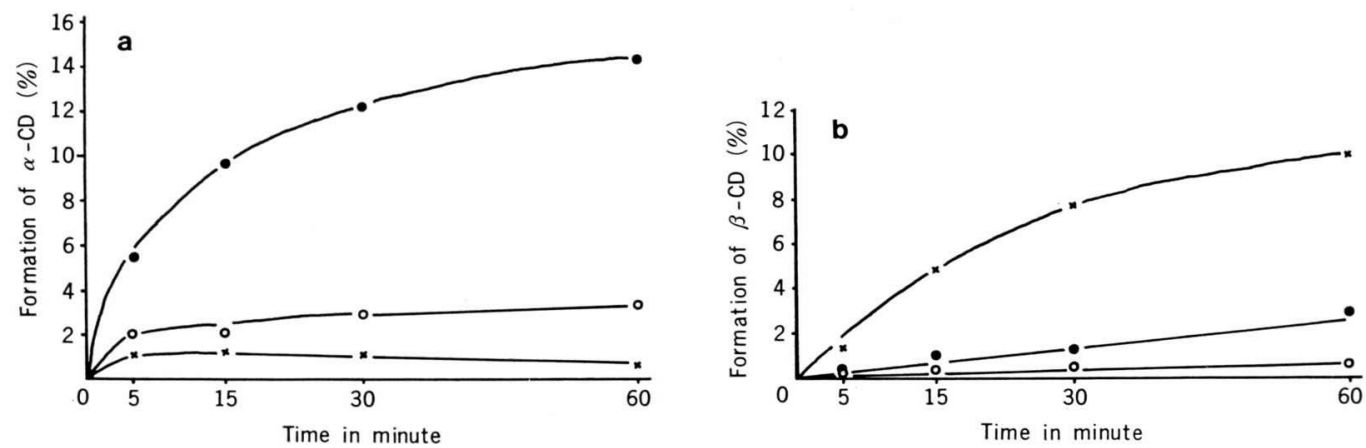

Fig. 6. a: Formation of $\alpha$-cyclodextrin with and without surfactants, b: formation of $\beta$-cyclodextrin with and without surfactants.

$\bigcirc$, Reference (without surfactant); $\bullet$, with No. 4 surfactant; $\times$, with No. 7 surfactant.

Formation was represented by percentage as total carbohydrate in the reaction mixture as 100 .

7 (Fig. 6a, 6b). The difference between Nos. 4 and 7 is hydrophobic moiety of the molecular structure. That is, hydrophobic moiety may act as main factor to form $\alpha$ and $\beta$-CD through forming different helices.

\section{Effect of SDS on hydrolyzing activity}

It is well known that SDS inhibits endo attack amylases. ${ }^{19)}$ This has been thought because the enzymes become difficult to attack the inner part of substrates which take helical structure with SDS. And SDS was very effective in repressing the hydrolyzing activity of BME (Fig. 7). This result suggests that BME attacks loose parts of the molecules to transfer the part to water, and when the molecules take helical structure, cyclization proceeds predominantly from non-reducing end. 


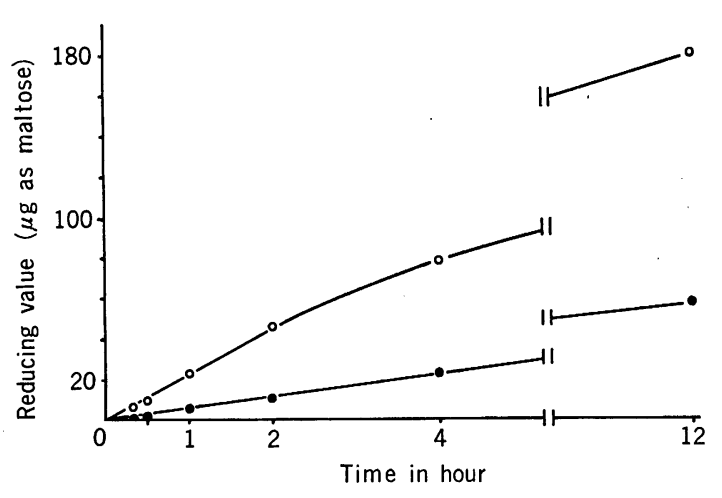

Fig. 7. Depression of hydrolyzing activity by SDS.

O, Reference (without SDS); $\bullet$, with SDS.

Refer to determination of hydrolyzing activity in Experimental.

\section{Effect of SDS on the enzyme protein}

There is another possibility, the enzyme may change its conformation with SDS, and may show different action patterns.

UV and circular dichroism spectra were used to solve this problem. The enzyme solutions (1.12 $\mathrm{mg} / 3 \mathrm{ml}$ of water) with and without SDS (final concentration $0.2 \%$ ) were prepared, kept at room temperature for $15 \mathrm{hr}$, and took UV spectra by use of SM-401 (Union Giken, Kyoto, Japan). For circular-dichroism spectra, $1.12 \mathrm{mg}$ protein $/ 2$ $\mathrm{ml}$ of water with and without SDS (final concentration $0.2 \%$ ) were prepared, and treated the solutions as same as UVs. The apparatus was $\mathrm{J}-20$ (Jasco, Tokyo, Japan).

No difference of the UV spectra of the enzyme was observed between with and without SDS. The circular dichroism spectra were also the same in the range of 250 to $300 \mathrm{~nm}$, but different in the range of 190 to $250 \mathrm{~nm}$.

The ORD (optical rotary dispersion) spectrum of the substrate with SDS was different from the one without SDS, probably due to the formation of helical complex. The authors infer that cyclization proceeds on helices from non-reducing end of substrates; $\alpha-C D$ is effectively formed by the addition of $6_{5}$ helix forming surfactants, and $\beta-C D$ is formed by the addition of $7_{6}$ helix forming surfactants.

The results suggest that the action pattern of BME depends not only on the specificity of the enzyme itself, but also on the conformation of the substrate as modified by helicogenic complexing agents. Even though, the authors could not entirely neglect the effect of conformational change of the enzyme on the change of action pattern.

\section{REFERENCES}

1) D. French: Adv. Carbohydr. Chem., 12, 189 (1957).

2) S. Kobayashi, K. Kainuma and S. Suzuki: Carbohydr. Res., 61, 229 (1978).

3) M.L. Levine: Ph. D. Thesis, Iowa State College (1947).

4) D. French, J. Pazur, M.L. Levine and E. NorBERG: J. Am. Chem. Soc., 70, 3145 (1948).

5) E. Norberg and D. French: J. Am. Chem. Soc., 72, 1202 (1950).

6) F. Cramer and D. Steink: Ann., 595, 81 (1955).

7) S. Kobayashi: Ph. D. Dissertation at the University of Tokyo (1977).

8) S. Kobayashi, K. Kainuma and S. Suzuki: Nippon Nogeikagaku Kaishi, 51, 691 (1977).

9) D. French, A.O. Pulley and W.J. Whelan: Stärke, 15, 280 (1963).

10) J.H. Pazur and T. Ando: Methods in Carbohydrate Chemistry, I, R.L. Whistler and M.L. Wolfrom eds., Academic Press, New York, p. 285 (1962).

11) D. French, A.O. Pulley, M. Abdullah and J.C. Linden: J. Chromatogr., 24, 271 (1966).

12) S. Kobayashi, B.M. Youns and D. French: in preparation.

13) M. Dubois, K.A. Gilles, J.K. Hamilton, P.A. Rebers and F. Smith: Anal. Chem., 28, 350 (1956).

14) M. Somogyi: J. Biol. Chem., 195, 19 (1952).

15) S. Kobayashi, K. Kainuma and S. SUzuKi: J. Jpn. Soc. Starch Sci., 21, 131 (1974).

16) T. Takagi and T. Isemura: Bull. Chem. Soc. Jpn., 33, 437 (1960).

17) E.M. Osman, S.L. Leith and M. Fles: Cereal Chem., 38, 449 (1961).

18) V.S.K. RAO and J.F. Foster: Biopolymers, 1, 527 (1963).

19) K. Sakon, T. Watanabe and S. Ono: Bull. Chem. Soc. Jpn., 43, 1000 (1970). 
バチルス・マセランスサイクロデキストリ

ングルカノトランスフェラーゼの環化

反忍における界面活性剂の影響

小林昭一・貝沼圭二・Dexter FRENCH*,†

農林水産省食品総合研究所

(305 茨城県筑波郡谷田部町観音台 2-1-2)

*前アイオワ州立大学生物物理学科

（アイオワ州，エームス市，U.S.A）

バチルス・マセランスサイクロデキストリングルカ, トランスフェラーゼ (BME) の環化反応を，各種の界面 活性剂を用いて検討した。還元末端を標識したマルトオ リゴ糖を用いて環化反応を検討した結果, 環化は, $a-1,4$ グルカンの非還元末端から進むことが明らかにされた。 また，疎水部分に直鎖炭素鎖をもつ界面活性剂は，酵素 の $\alpha$-サイクロデキストリン $(\alpha-C D)$ 生成反応を著しく †1981年11月26日逝去.
促進した。一方，直鎖炭素鎖より大きな踈水部分をもつ 界面活性剤は $\beta-\mathrm{CD}$ 生成に効果的であった。

脱脂モチトウモロコシ激粉から, 細菌の液化型 $\alpha-ア ミ$ ラーゼと $\beta$-アミラーゼ処理により調製したデキストリ ンでは, SDS 無添加でごく少量の CD しか生成されな いが，このデキストリンを用い， $\alpha-\mathrm{CD}$ 形成用界面活性 剂を加えて，主として $\alpha-\mathrm{CD} を ＼mathrm{~ を た ~} \beta-\mathrm{CD}$ 形成用界 面活性剂を加えて，主として $\beta-\mathrm{CD}$ を生成するように酵 素作用を変化させることができた。

可溶性澱粉を用いたときの $\alpha-\mathrm{CD}$ 生成速度は, SDS （ラウリル硫酸ソーダ）添加によって無添加のときより

1.6 倍速くなった。

これらの結果から筆者らは環化反応は $\alpha-1,4$ グルカ ンの非還元末端から 65-ラセンまたは 76-ラセンを形成 しながら進み， $\alpha$ または $\beta-\mathrm{CD}$ を生成し，したがって， BME の作用パターンの変化は酵素の特異性のみならず, ラセン形成試薬によって基質の構造が変化することによ っても起こると推論した。 